\title{
A Global Screening Assay to Select for Maize Phenotypes with a High Tolerance or Resistance to Fusarium verticillioides (Sacc.) Nirenberg Rots
}

\author{
Shamir Gabriel Román ${ }^{1, \dagger}$, Jesús Quiroz-Chávez ${ }^{1, \dagger}$, Miguel Villalobos ${ }^{2}$, \\ Vianey Urías-Gutiérrez ${ }^{1}$, Eusebio Nava-Pérez ${ }^{1}$, Eliel Ruíz-May ${ }^{3}{ }^{\circledR}$, Rupesh Kumar Singh ${ }^{4}$, \\ Lav Sharma ${ }^{5}$ and Francisco Roberto Quiroz-Figueroa ${ }^{1, * \mathbb{D}}$ \\ 1 Instituto Politécnico Nacional, Centro Interdisciplinario de Investigación para el Desarrollo Integral Regional \\ Unidad Sinaloa (CIIDIR-IPN Unidad Sinaloa), Laboratorio de Fitomejoramiento Molecular, \\ Blvd. Juan de Dios Bátiz Paredes no. 250, Col. San Joachín, Guasave 81101, Sinaloa, Mexico; \\ shamir_336_hatch@hotmail.com (S.G.R.); yesck_pbs@hotmail.com (J.Q.-C.); \\ vianeyselena09@hotmail.com (V.U.-G.); eusebionavaperez@yahoo.com.mx (E.N.-P.) \\ 2 Híbridos Lobo SA de CV, Departamento de Investigación, Av. Guerrero 330 Int 2, Cuauhtémoc 31500 , \\ Chihuahua, Mexico; miguel.villalobos139@gmail.com \\ 3 Red de Estudios Moleculares Avanzados, Instituto de Ecología A. C., Cluster BioMimic ${ }^{\circledR}$, \\ Carretera Antigua a Coatepec 351, Congregación el Haya, Xalapa 91070, Veracruz, Mexico; \\ eliel.ruiz@inecol.mx \\ 4 Departamento de Agronomia, Universidade de Trás-os-Montes e Alto Douro (UTAD), Quinta de Prados, \\ 5000-801 Vila Real, Portugal; rupesh@utad.pt \\ 5 Syngenta Ghent Innovation Center, Devgen NV, Technologiepark 30, 9052 Gent-Zwijnaarde, Belgium; \\ lavhere@gmail.com \\ * Correspondence: labfitomol@hotmail.com \\ + These authors contributed equally to this manuscript.
}

Received: 11 November 2020; Accepted: 10 December 2020; Published: 18 December 2020

\begin{abstract}
Fusarium verticillioides (Sacc.) Nirenberg (Fv) causes rots in maize around the world and produces mycotoxins that contaminate grains, making this species a significant health concern for both animals and humans. One of the best approaches to address rots is to identify highly tolerant or resistant genotypes that can be used for genetic improvement. The aim of the study was to evaluate dose-response assays to tolerance or resistance for $F v$ rots throughout the maize life cycle. These tests assessed the effects of $F v$ during post-germination development and the seedling (V2) stage by seed infection, the plantlet (V4) stage by substrate infection, and in the reproductive phase in maize stalks (R2 stage) and ears (R6 stage) by R1 stage inoculation. In all assays, the doses were effective at distinguishing contrasting phenotypes. Severity, root fresh weight, and aerial length were the most informative parameters at the V2 and V4 stages. Evaluation of the stalk necrosis area between and within the internodes of susceptible genotypes revealed significant differences among doses, and a positive correlation between necrosis and conidia concentration was observed in internodes. Injecting eight million conidia in the ear was sufficient for selecting different phenotypes. A total of $85 \%$ of the genotypes conserved their same capacity to respond to Fv infection throughout the maize life cycle, so that screening at the early vegetative stage (e.g., V2) could be useful for distinguishing contrasting phenotypes in the reproductive stage. Implementing these screening assays in a maize breeding program could be valuable for classifying the degrees of resilience of maize germplasms to $\mathrm{Fv}$ rots. This global screening has the potential to be employed to select against other Fusarium species.
\end{abstract}

Keywords: fusariosis; maize breeding; Zea mays L. 


\section{Introduction}

Maize (Zea mays L.) is one of the most important crops worldwide. Due to its high demand as an important food resource for humans and animals, and as a raw material for use in industry and biofuels [1], maize production is increasing at a faster rate than other cereals [1,2]. However, maize mono-cropping and its genetic homogeneity (due to a narrow genetic pool of commercial hybrids used extensively in agriculture) enable the establishment of pathogens [3,4]. Fungi are the most critical phytopathogens in maize agriculture, among which Fusarium spp. are one of the main concerns since they can infect roots, stalks, kernels, and ears [5,6]. Consequently, Fusarium can provoke rots that affect maize yield and grain quality by producing fumonisin or deoxynivalenol (also known as vomitoxin or DON) mycotoxins [7-9]. The amount of toxins found in grains used for food production or feeding must; therefore, be taken into consideration, since they are harmful to both animal $[10,11]$ and human health [12-15].

Fusarium species are distributed widely throughout maize fields and have been reported in 126 countries around the world [16,17]. For example, 13 species have been identified in Germany, where F. verticillioides (Sacc.) Nirenberg and F. graminearum Schwabe were the most predominant species in 2006 and 2007, respectively [18]. Similarly, 15 species have been isolated from grains and husks in New Zealand, in which the F. verticillioides and F. graminearum species complexes represent the majority of the identified isolates [19]. Four species (F. verticillioides, F. andiyazi, Marasas et al., F. nygamai Burgess \& Trimboli, and F. thapsinum, Klittich et al.) have been identified in commercial seeds from Mexico, of which F. verticillioides was the most frequently isolated species from seeds [20]. Fusarium spp. have also been detected in other countries including Spain [21], Brazil [22], South Africa [23], Canada, and the USA $[24,25]$. Fv being one of the main species identified in agricultural fields.

Maize is the most important crop in Mexico, and its annual production in 2019 was ca. 27.22 million tons, such that ca. $52.2 \%$ of seasonal fields are dedicated to this crop [26]. Nevertheless, information is limited regarding Fusarium incidence, species, and the mycotoxins produced. In the central and southern regions of Mexico, maize yield losses caused by ear rot are between 7-43\% [27,28], whereas maize production is considerably hampered by fusariosis incidence in the southeastern part of the country [29]. Sinaloa state is the largest producer of maize in Mexico, and cornfields in the north and southcentral parts of the state can display up to $84 \%$ and $40 \%$ infection by Fusarium spp., respectively [30,31], consequently decreasing corn yield by 10-25\% [8]. Fusarium species are not only limited to Sinaloa, since they have also been reported in 10 out of 32 states including Jalisco, Veracruz, Mexico, Chiapas, and Puebla [17]. These species could; thus, be present in all Mexican maize fields.

Fusarium can infect maize at every single plant stage. The fungus can easily penetrate damaged roots, stalks, and leaves, as well as young grains through the silk channel [32,33]. Furthermore, Fusarium conidia can survive for long periods of time within harvested dry kernels, which can transmit the infection to the next generation $[16,20,34]$. Fusarium parasitize as hemibiotrophs, meaning that they have a biotrophic phase on a living host followed by a necrotrophic phase on dead tissue [35]. Importantly, this means that after threshing, Fusarium spp. can live and remain within crop residues in fields, ready to infect plants again in the next crop cycle [36]. In this context, the use of resistant or highly tolerant maize genotypes for all plant development stages should help to reduce the presence of this pathogen in fields, as well as levels of mycotoxins in grains and by-products.

As noted above, one of the most effective strategies for controlling Fusarium rot infections and decreasing fumonisin contamination is the selection of highly tolerant or resistant maize genotypes [37]. However, breeding programs mainly select for ear rots, since it is the easiest Fusarium symptom to discriminate among genotypes in the field [38]. This selection is only feasible when the environmental conditions are favorable for the pathogen that allows visible symptoms. The first step to select resistance or tolerance against Fusarium spp. in a breeding program is to establish an effective protocol to differentiate among genotypes at vegetative and reproductive stages. Inoculation techniques must have a sufficient response level to induce measurable changes in the fitness of the plant or cause damage that can be effective scored as indicative of resistant or tolerant individuals [39]. Individual Fusarium 
inoculation assays have been conducted in seeds and the post-germinative stage [40], in seedlings and plantlets [20], in stalks [41,42], in ear kernels [41-44], and in soil infestations [42]. To our knowledge, no report has yet identified which genotypes are tolerant or susceptible to Fv or other Fusarium specie at each development stage of the plant. The objective of this study was; thus, to determine whether different $F v$ dose-response assays could be used to select tolerance or resistant phenotypes throughout the maize life cycle.

\section{Materials and Methods}

\subsection{Biological Material}

Seven elite maize inbred lines (IL) were used. These lines were derived from proprietary white, dent, and flit grain populations by conventional breeding after eight cycles of recombination and selfing. The lines are mainly adapted to the sub-tropical northwest of Mexico. For fungal inoculation in all stages of the plant cycle, we used the previously characterized, highly virulent Fv strain DA42, kindly provided by Dr. Ignacio Maldonado-Mendoza [20]. This strain was isolated from maize fields from the same northwestern region of Mexico, where the inbred lines tested are well adapted.

\subsection{Decontamination of Seeds}

Seeds were surface-disinfected by sonication (Ultrasonic Bath 2.8L, Fisher Scientific, Pittsburgh, PA, USA) in sterile distilled water with Tween 20 (5 drops of Tween 20/100 mL of distilled water) for $5 \mathrm{~min}$. Subsequently, seeds were immersed in $1.5 \%(\mathrm{~V} / \mathrm{V})$ sodium hypochlorite at $52{ }^{\circ} \mathrm{C}$ for 20 min (Thermobath FE-377, Felisa, Zapopán, Mexico), rinsed three times in sterile distilled water, and air dried in a Class II Type A2 Biological Safety Cabinet (Herasafe KS, Thermo Scientific, Langenselbold, Germany).

\subsection{Conidia Suspensions and Inoculation of Maize Seeds by Fv}

The Fv strain was cultivated in Spezieller Nährstoffarmer Agar medium (SNA) with a $1 \mathrm{~cm}^{2}$ filter paper [45] supplemented with neomycin $(120 \mathrm{mg} / \mathrm{L})$ and streptomycin $(1 \mathrm{mg} / \mathrm{L})$, and cultivated at $25 \pm 2{ }^{\circ} \mathrm{C}$ for seven days [20]. Conidia were harvested by adding $5 \mathrm{~mL}$ of sterile saline solution $(0.8 \% \mathrm{NaCl})$ to the culture medium with gentle shaking. The conidia quantification was performed in a Neubauer chamber using a light microscope (B-383-M11, Optika, Ponteranica, Italy). Finally, working suspensions were prepared at the concentration of inoculation. For each assay, surface-disinfected seeds were immersed in the working suspension for five min.

\subsection{Fv Effect on the Post-Germination of Maize Emergencia (VE Stage)}

The rolled paper technique [40] was used in this assay. Five seeds were placed per treatment $(0,1$, 1.5 and $2 \times 10^{6}$ conidia/mL) on sterile Kraft paper $(19 \times 32 \mathrm{~cm})$ moistened with sterile water, rolled, and placed in Ziploc bags in a growth room on a 16:8 h light:dark photoperiod and 70\% humidity for 4 days. The length and fresh weight of the coleoptile and roots were measured. The experiment was repeated three times independently with four replicates $(n=20)$.

\subsection{Fv Effect on Maize Seedlings at the Second Leaf Collar (V2 Stage)}

The control and three doses of infected seeds $\left(0,0.5,1\right.$ and $1.5 \times 10^{6}$ conidia/mL) were evaluated. The seed infection procedure and the growth conditions of the seedlings were similar to the post-germination experiment, with the exception of a 14-day test period. Plant height and the fresh weight of roots and shoots were all recorded according to Roman [17], and root severity were assessed using a previously proposed scale by García-Espinoza [46]. The experiment was repeated three times independently with three replicates $(n=15)$. 


\subsection{Fv Effect on Maize Plantlet at the Fourth Leaf Collar (v4 Stage) in Greenhouse}

Fv was cultivated in PDA medium acidified with lactic acid $(0.5 \mathrm{~mL}$ lactic acid per $0.5 \mathrm{~L}$ of medium) after sterilization. A total of $600 \mathrm{~g}$ of broken corn hydrated with $0.24 \mathrm{~L}$ of distilled water were sterilized at $121^{\circ} \mathrm{C}$ for $60 \mathrm{~min}$. The sterile broken corn was then inoculated with 18 cylinders (7 mm diameter) of $\mathrm{Fv}$ mycelia and incubated for seven days at $25 \pm 2{ }^{\circ} \mathrm{C}$. Next, different doses $(0,25$, 50,75 and $100 \mathrm{~g}$ ) of inoculated broken maize (ca. $1 \times 10^{6}$ conidia/g) were evaluated in pots containing $3 \mathrm{~kg}$ of sterile sand:vermiculite substrate (1:1). The negative control included sterile broken corn but without fungi inoculation. The ground corn was manipulated as described above. We used a control concentration of $50 \mathrm{~g}$ ground corn per $1 \mathrm{~L}$ of substrate. Surface-disinfected seeds were germinated on PDA medium for three days, and only non-infected seeds were planted in the pots. The greenhouse was maintained at $25 \pm 2{ }^{\circ} \mathrm{C}$ with natural lighting. Plants were watered with $80 \mathrm{~mL}$ of tap water and fertilized every 14 days with $80 \mathrm{~mL}$ of nutritive solution containing $216.2 \mathrm{~g} / \mathrm{L}$ urea, $159.05 \mathrm{~g} / \mathrm{L}$ NKS (Ultrasol NKS 46, SQM, Santiago, Chile), $53.5 \mathrm{~g} / \mathrm{L}$ MAP (Ultrasol MAP, SQM, Santiago, Chile) and $2 \mathrm{~g} / \mathrm{L}$ of micronutrients (Ultrasol micro, SQM, Santiago, Chile). The experiment was evaluated after 30 days, and the aerial height, fresh and dry weight of shoots and roots, and severity variables were all analyzed according to the scale proposed by Soonthornpoct et al. [47]. Briefly, the disease rating was recorded as a root disease index (RDI) based on a scale of $0-5$, where $0=$ no symptom on roots, $1=<25 \%$ of roots symptomatic for lesions, $2=25-49 \%, 3=50-74 \%, 4=75 \%$ or greater, and $5=$ wilted or dead seedlings. The experiment was repeated three times independently with five replicates.

\subsection{Fusarium Effect in Stalks at the Silking (R1 Stage)}

Seeds were planted in the CIIDIR-IPN Sinaloa experimental fields on an autumn-winter agricultural cycle during 2016, 2017, and 2018. Each treatment consisted of a $3 \mathrm{~m}$ block that included 21 plants (seven plants $/ \mathrm{m}$ ). The fertilization solution was made up of $4.383 \mathrm{~kg}$ urea, $2.19 \mathrm{~kg}$ NKS, $1.54 \mathrm{~kg}$ MAP and $0.0346 \mathrm{~kg}$ of micronutrients per ha, and fertilization was performed once per week for $3 \mathrm{~h}$. For this assay, $50 \mu \mathrm{L}$ with $0,1,2$ or $3 \times 10^{6}$ million conidia were injected into plant stalks when $\geq 50 \%$ of the female inflorescence stigmas per block reached ca. $5 \mathrm{~cm}$ in length. All plants were injected in the first and second stalk internodes above ground. The infection was allowed to propagate for 30 days after injection, after which plants were harvested and analyzed using the ImageJ program [48]. The data for infected stalks were subtracted from the control stalk data (i.e., infected data minus control data) so that the only effect would be the action of the fungus; this also eliminates the mechanical damage caused by the injection. The experiment was repeated independently 3 times $(n=21)$.

\subsection{Fv Effect on Ears at the Maturity (R6 Stage)}

During the flowering period, plants of the same genotype were pollinated fraternally 14 days after the ears (R1 stage) were inoculated with injections at their base and the central ear. For the control injections, $2 \mathrm{~mL}$ of saline water was used $(0.8 \% \mathrm{NaCl})$, and four million conidia per site were used in the treatments. The incidence of ear rot was analyzed at the end of the life cycle as the percentage of grains infected (brown seeds) and compared to the uninfected ear control (white or yellow seed color) [49]. The experiment was independently repeated twice $(n=21)$ at the CIIDIR-IPN Sinaloa experimental fields on an autumn-winter agricultural cycle during 2016-2017.

\subsection{Statistics Analysis}

For the VE, V2, and V4 stages, the infected treatments were analyzed relative to their controls, and uninfected treatments were considered to be $100 \%$ (dashed line), while the effect of the Fv assay was deemed to be negative below this level. We calculated the similarity percentage [17] as $100-((\mathrm{CP}-\mathrm{IP}) / \mathrm{CP}) \times 100$, where $\mathrm{CP}$ represented the control plant and IP is the infected plant. The similarity percentages were then plotted. For the reproductive stages, the experiments were performed in two independent lots with 24 blocks per lot, and the treatments were distributed using 
a completely randomized block design. Data from each assay was analyzed for variance (ANOVA), cluster analysis and the Duncan Means Test $(\alpha \leq 0.05)$ using the SAS software for Windows version 9.0 (SAS Institute, Inc.; Cary, NC, USA) and the RStudio (Version 1.3.1093). Statgraphics version 16.1.02 was used to calculate the Pearson correlation coefficient between factors. The hierarchical clustering analysis was performed with data from severity, fresh root weight, and aerial length using the Statgraphics Centurion XVI versión 16.1.03 (StatPoint Technologies, Inc., The Plains, VA, USA, 1982-2010). Origin version 8.5.1 SR2 and CorelDraw version 17.1.0.572 were used to make the graphs and figures, respectively.

Note: Two different IL were used for the dose-response assays. For the global screening, seven IL and the dose that could discriminate among contrasting genotypes were evaluated.

\section{Results}

\subsection{Fv Infection Does Not Diminish Growth at the Post-Germinative Stage (Seed Rot)}

In order to identify the contrasting maize phenotypes in response to the Fv effect on post-germinative growth (VE stage), genotypes were challenged with $F v$ in rolled paper assays for four days. We performed dose-response analyses for 1, 1.5 and 2 million conidia/mL (Figure 1). In most cases, these treatments resulted in a slightly negative change associated with the growth of roots or coleoptiles. However, there were differences between genotypes such as IL10, which exhibited an average decrease in the percent similarity of coleoptile length from $95 \%$ to $78 \%$. This reduction is supported by the decrease in the percent similarity of coleoptile fresh weight from $100 \%$ to $70 \%$. Treatment with one million conidia did not have any effect when compared with the control (dashed line at $100 \%$ ). In contrast, treatments with 1.5 and 2 million conidia exhibited significant differences as compared to the control $(p \leq 0.01 ; \mathrm{n}=15)$. Seeds infected with $F v$ displayed a contrasting effect, observed as an increase in growth. The IL10 genotypes did not significantly differ in growth with respect to the control (Figure 1a,c,e). In contrast, there was a positive Fv effect on the IL17 genotype. The three treatments increased coleoptile growth from 110 to $125 \%$ (Figure 1a,b,d), whereas root fresh weight was increased from $122 \%$ to $150 \%$ vs. the control (Figure 1a,c,e). The two-way analysis of variance (ANOVA) of the inbreed lines, inoculum doses, and interaction effects is summarized Table S1.

\subsection{Fv-Infected Seeds Were Differentially Affected at the V2 Stage (Seedling Root Rot)}

Maize seeds were infected with $0.5,1$ or $1.5 \times 10^{6}$ conidia/mL in order to classify tolerant and susceptible genotypes. The three doses effectively revealed contrasting phenotypes (Figure 2). The IL10 genotype displayed drastic inhibition in the aerial and root tissues, with a reduction representing more than half of the growth of the control samples (Figure 2a). The highest dose, which had the most negative effect on growth, displayed statistically significant differences for seedling severity and the fresh weight of roots (Figure 2b-e). Whereas the IL17 genotype was less affected than the IL10 genotype, seedling severity was below $25 \%$ in all treatments, without any statistically significant differences (Figure 2b). The percent similarity between aerial tissue and root tissue ranged from $70 \%$ to $90 \%$ (Figure 2c-e). When the IL10 and IL17 genotypes were compared, significant statistical differences were observed among all evaluated parameters. For example, IL10 was more drastically affected by Fv than IL17. ANOVA (Table S2) revealed a significant effect of genotype and doses, significant genotype and doses interaction confirmed the importance of the fungi doses applied to genotypes at this stage of maize development. In addition, strong negative correlations were observed between seedling severity and height $(\mathrm{r}=-0.77 ; p<0.01 ; \mathrm{n}=15)$, and between seedling severity and the fresh weight of aerial parts $(\mathrm{r}=-0.78 ; p<0.01 ; \mathrm{n}=15)$. In contrast, a weak negative correlation was observed between seedling severity and root fresh weight $(\mathrm{r}=-0.63 ; p<0.01 ; \mathrm{n}=15)$. 
(a) Conidia concentration $\left(1 \times 10^{-6}\right.$ Conidia $\left./ \mathrm{mL}\right)$
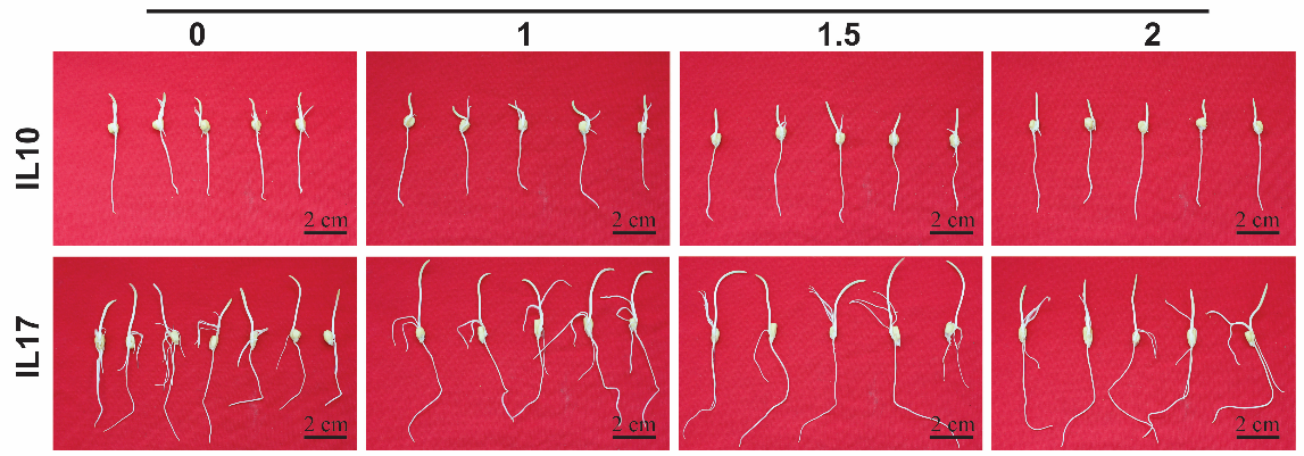

(b)

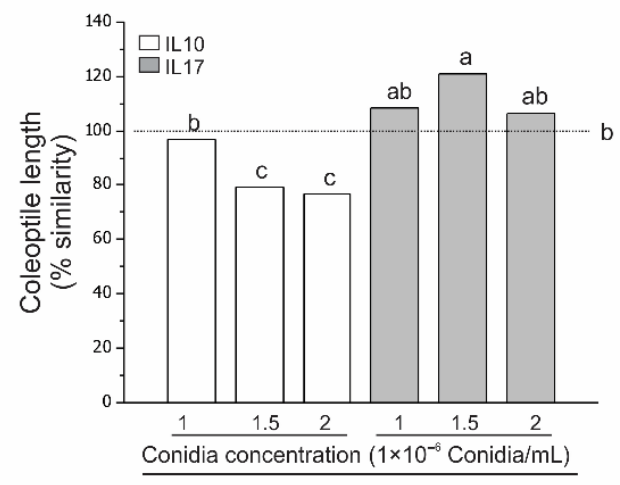

(d)

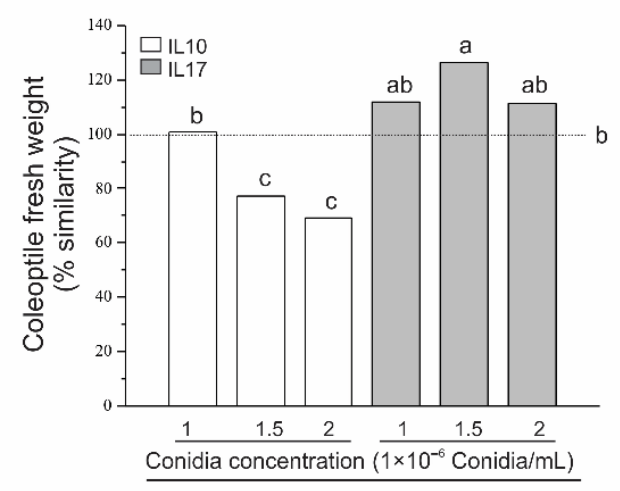

(c)

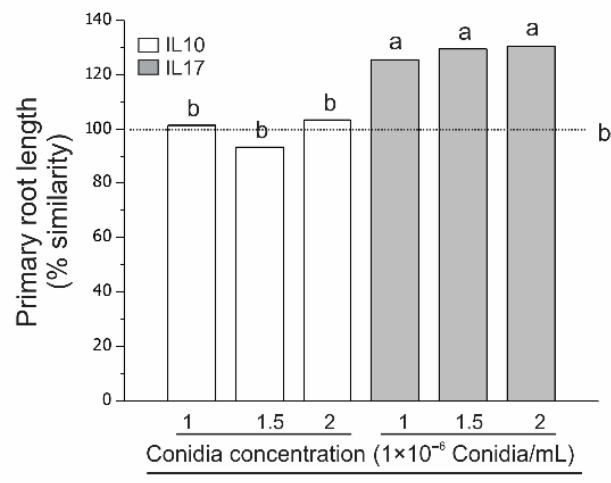

(e)

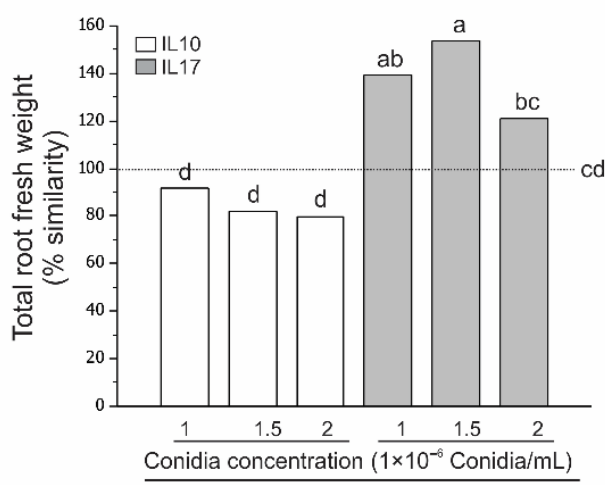

Figure 1. Fusarium effect on the post-germination of maize emergence (VE stage). (a) Lines IL17 and IL10 non-infected and infected with Fusarium verticillioides at four days post-inoculation. Seedlings were infected with different $F$. verticillioides conidia concentrations: $0,1,1.5$ or $2\left(1 \times 10^{-6}\right.$ conidia/mL). Data for (b) coleoptile length, (c) primary root length, (d) coleoptile fresh weight, and (e) root fresh weight were collected and analyzed for their similarity to the control plants (without infection). The different letters above the bars refer to significant differences using the Duncan means test $(\alpha=0.01 ; n=15)$. The dashed line at $100 \%$ represents the control value. The experiments were performed three times with a completely randomized design. 
(a)

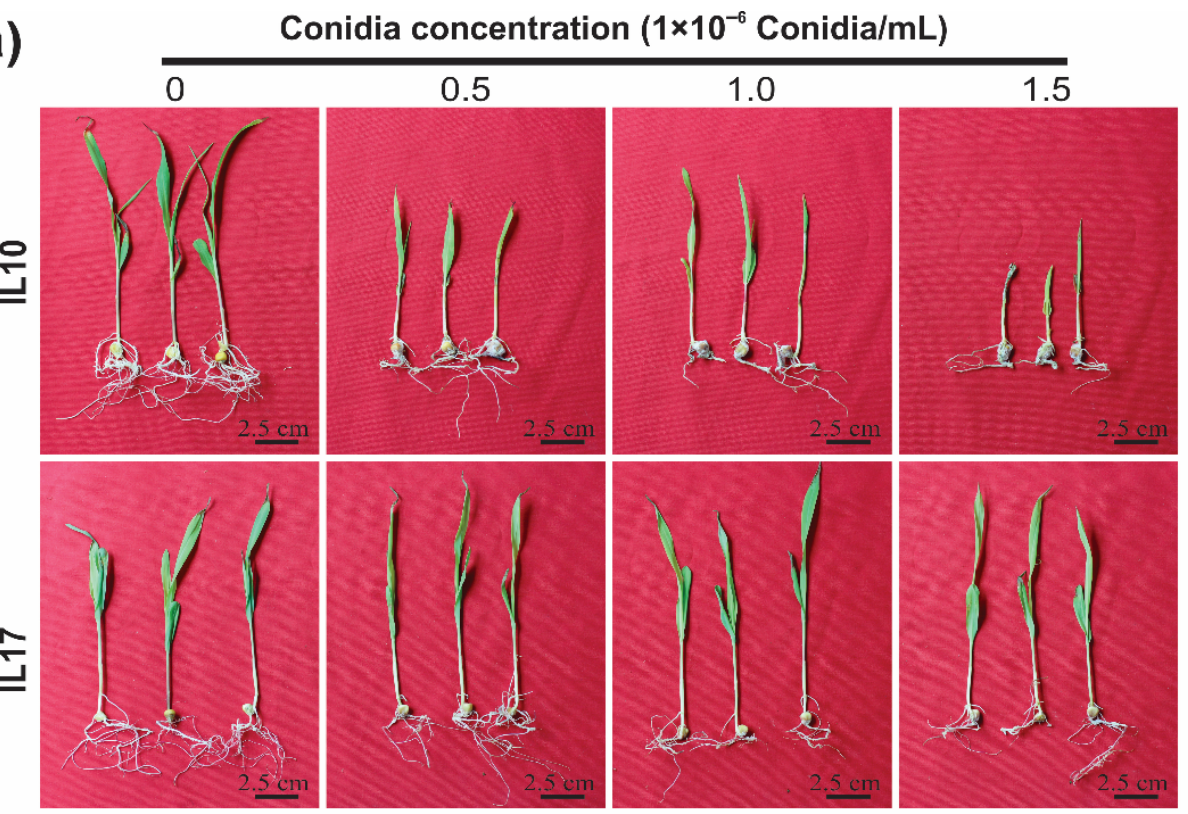

(b)

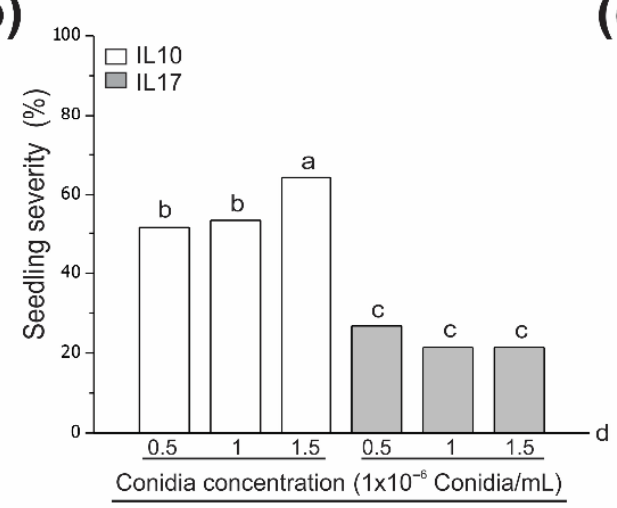

(d)

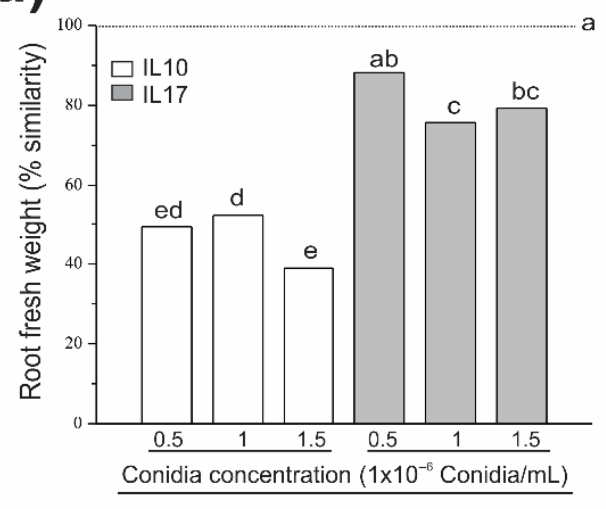

(c)

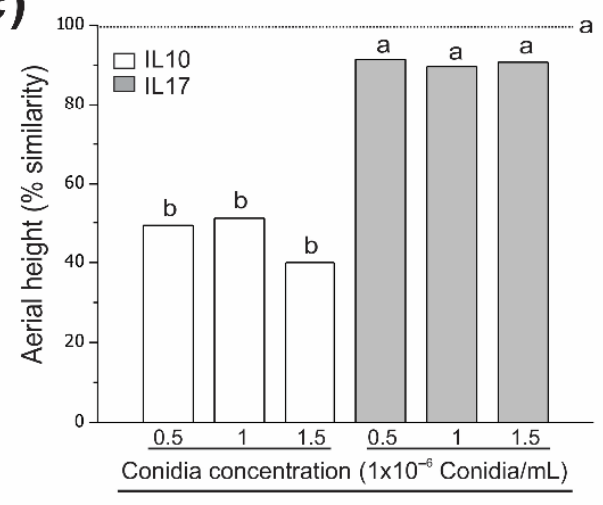

(e)

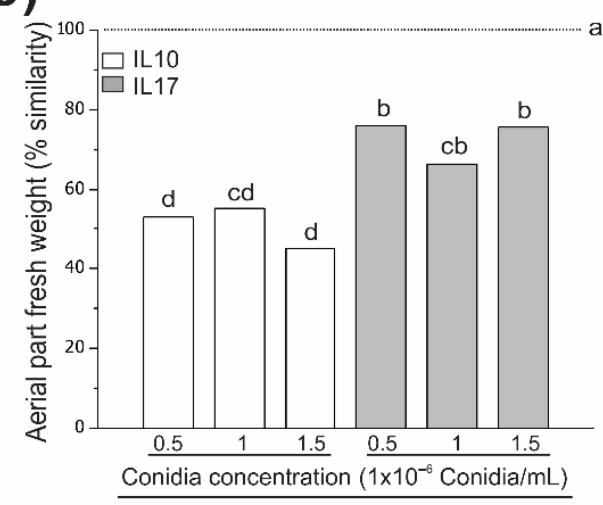

Figure 2. Fusarium effect on maize seedlings at the second leaf collar (V2 stage). (a) Seedling phenotypes subjected to the rolled paper assay. The evaluations for (b) seedling infection severity, (c) aerial height, (d) root fresh weight, and (e) aerial part fresh weight were recorded 14 days post-inoculation. Similarities in recorded data were determined for each treatment according to its control. The different letters above the bars refer to significant differences using the Duncan mean test $(\alpha=0.01 ; n=15)$. The dashed line at $100 \%$ represents the control value. The experiments were performed three times with a completely randomized design. 


\subsection{Fv Drastically Affects Susceptible Genotypes at the V4 Stage (Plantlet Root Rot)}

Maize plantlet blight caused by $F v$ is a destructive disease in the first week after planting [50] that can be prevented or diminished with the use of resistant or highly tolerant genotypes. The Fv dose-response effect was evaluated in the greenhouse in the fourth week after seed sowing, and it was possible to distinguish contrasting phenotypes in all evaluated doses (Figure 3a). The plantlet severity in IL14 ranged from $20 \%$ to $40 \%$, whereas the severity in IL12 was $40 \%$ to $100 \%$ during treatments with Fv (Figure 3b). Both aerial and root tissues were affected, with aerial length decreasing from $70 \%$ to $10 \%$ similarity for IL12. In contrast, the aerial tissue in IL14 decreased from $95 \%$ to $70 \%$ similarity in comparison to the control sample (Figure 3c). The responses for root fresh weight and aerial tissues infected with $F v$ were dose-dependent (Figure 3d,e). In response to the lowest dose, the IL12 genotype displayed $20 \%$ similarity with respect to the fresh weight of untreated roots, whereas root fresh weight percentages of similarity were very close to $2.5 \%$ for the two highest doses with respect to the control. Moreover, non-significant statistical differences were observed between these two doses. Unlike the IL14 genotype, which displayed over $62 \%$ similarity at the lowest dose (12.5 g), the IL12 and IL14 genotypes differed by more than $40 \%$. When comparing the highest dose from IL14 with the lowest dose from IL12, no significant statistical differences were observed (Figure 3d). The fresh weight of the aerial tissue in the IL12 and IL14 genotypes (Figure 3e) displayed a similar trend to that observed for the fresh weight of roots. There were significant differences between genotypes, doses, and the interaction genotype:dose as described in the ANOVA (Table S3). Negative correlations between severity and aerial part length $(\mathrm{r}=-0.84 ; p<0.01 ; \mathrm{n}=15)$, root fresh weight $(\mathrm{r}=-0.80 ; p<0.01 ; \mathrm{n}=10)$ and aerial part fresh weight $(\mathrm{r}=-0.77 ; p<0.01 ; \mathrm{n}=15)$ were observed.

\subsection{Fv Stalk Rot Affects Stalk Internodes at a Similar Level on the Same Genotype}

Fv stalk rot is capable of inducing premature plant death or yielding losses in maize [51-53]. It is; therefore, desirable for breeding programs to be able to identify maize genotypes with a high tolerance to this rot. Thus, we directed this part of the analysis to evaluate the dose-response of the $F v$ effect in stalks. Three doses of different $F v$ conidia concentrations were evaluated, and contrasting phenotypes were observed (Figure 4). The IL11 genotype was the most affected and exhibited infection grade increments of approximately $15-20 \%, 30-35 \%$, and $42.5 \%$ in response to one, two, and three million conidia, respectively. Furthermore, statistical differences were observed within internodes at the different conidia concentrations. However, we could not visualize differences in the necrosis area between the first and second internodes (Figure 4c,d, white bars). In contrast, the IL2 genotype displayed a reduced necrosis area of $10-15 \%$ for the first internode and $7.5-10 \%$ for the second internode, although there were no statistical differences among the doses. The correlation coefficient of the doses and necrosis area for IL11 had a strong positive correlation $(r=0.77$ and $0.64 ; n=10$ and $n=33$ with $p<0.01$ for the first and second internodes, respectively), whereas IL2 had a weak or negligible relationship $(\mathrm{r}=-0.42$ and $0.006 ; \mathrm{n}=26$ and $\mathrm{n}=10$ with $p<0.01$ for the first and second internodes, respectively). The ANOVA revealed significant differences in the source of variance (Table S4). These results confirm that it is feasible to differentiate between resistant and susceptible genotypes, and that our approach could be easily implemented in breeding programs for improving $F v$ genetic resistance. 
(a)
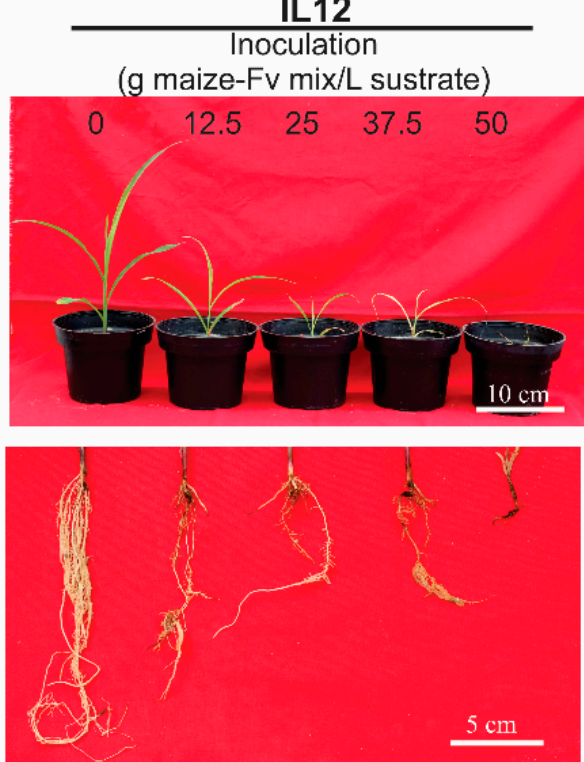

(b)

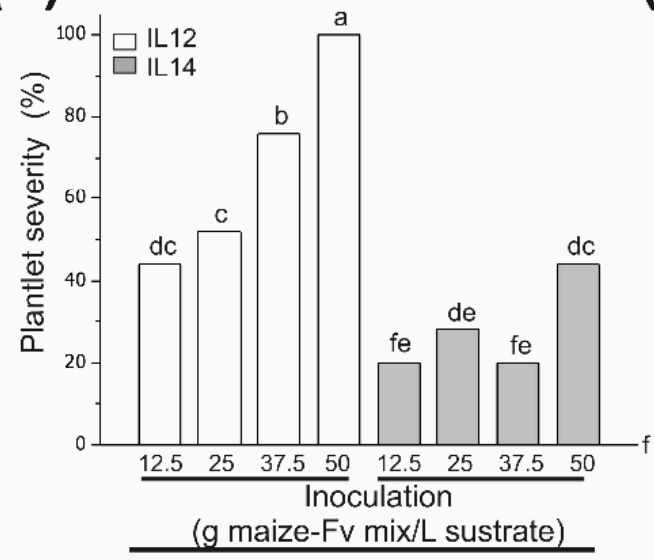

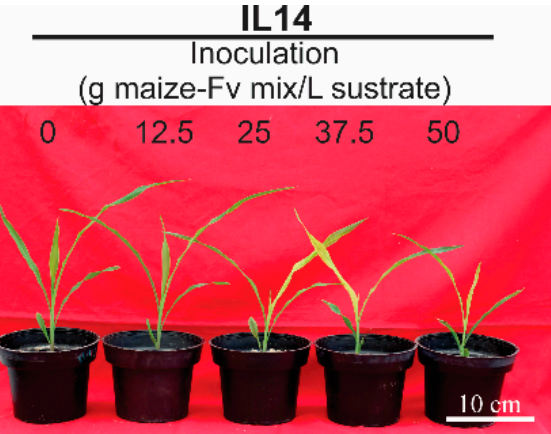

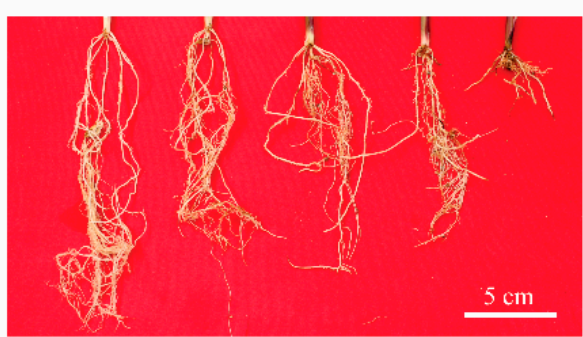

(c)

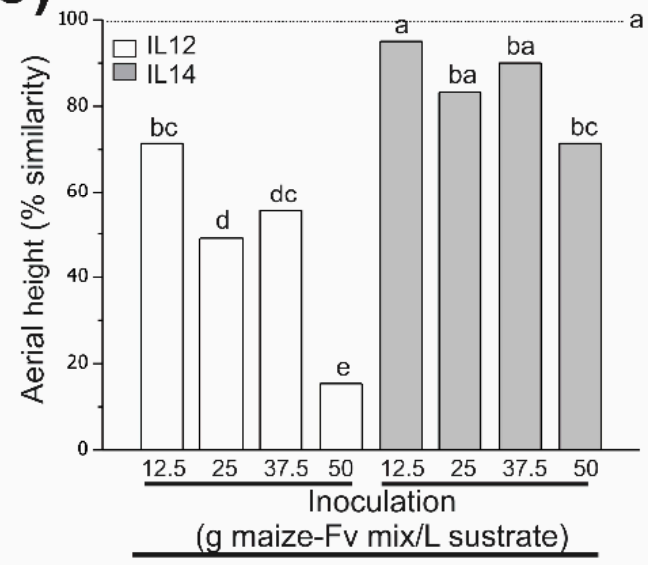

(d)

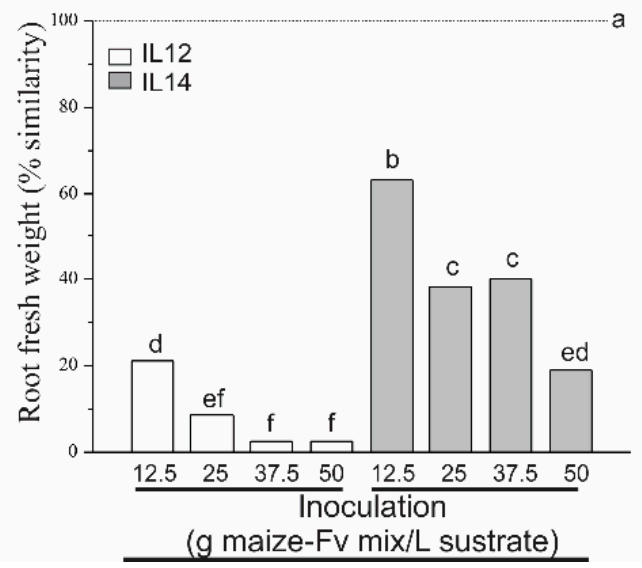

(e)

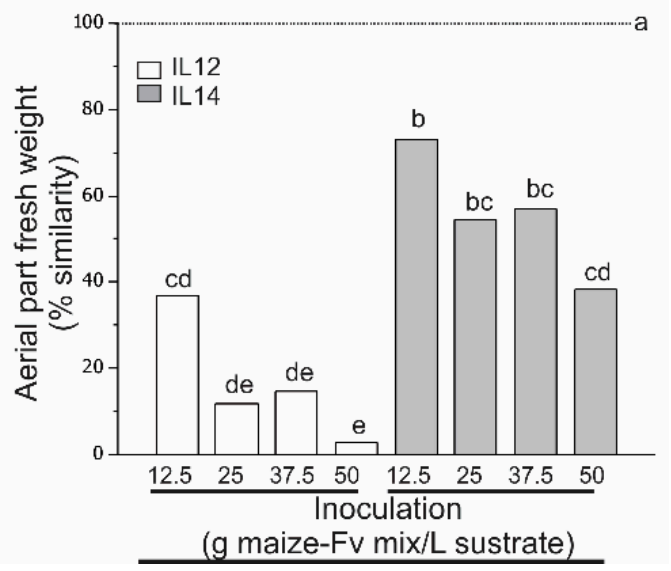

Figure 3. Fusarium effect on maize plants at the fourth leaf collar (V4 stage). (a) The aerial part and root development phenotypes are shown under different inoculum concentrations. The evaluation was made 30 days after transplanting. For quantitative evaluations of plantlet severity (b), aerial height $(\mathbf{c})$, root fresh weight $(\mathbf{d})$, and aerial fresh weight $(\mathbf{e})$, the similarities were determined according to their controls. The different letters above the bars refer to significant differences using the Duncan mean test $(\alpha=0.01 ; n=5)$. The dashed line at 100\% represents the control value. The experiments were performed three times with a completely randomized design. 
(a)
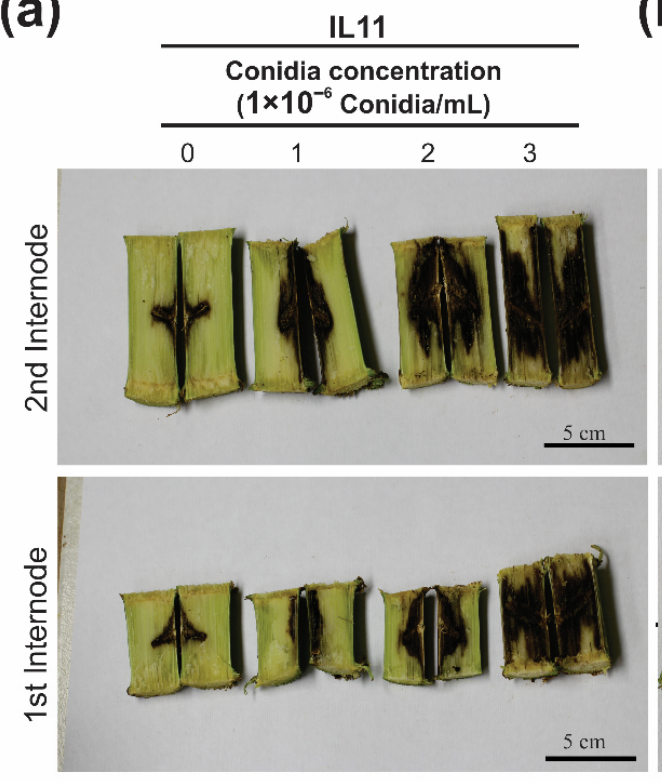

(c)

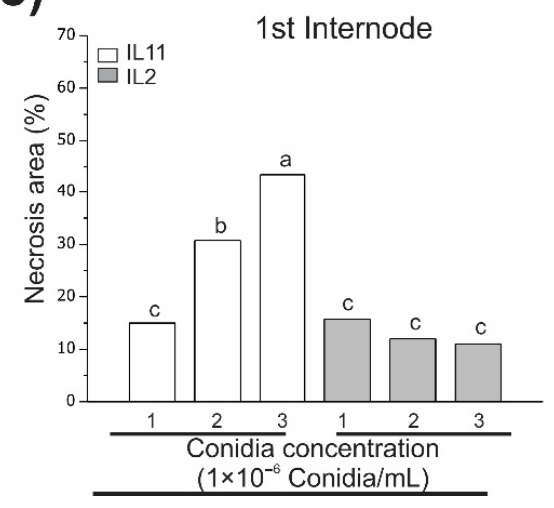

(b) IL2

\begin{tabular}{cccc}
\hline & $\begin{array}{c}\text { Conidia concentration } \\
\left(1 \times 10^{-6} \text { Conidia } / \mathrm{mL}\right)\end{array}$ & \\
\hline 0 & 1 & 2 & 3
\end{tabular}
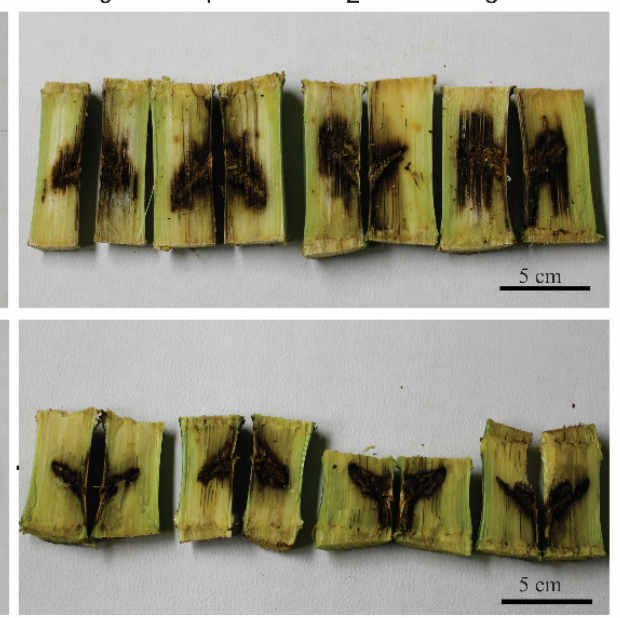

(d)

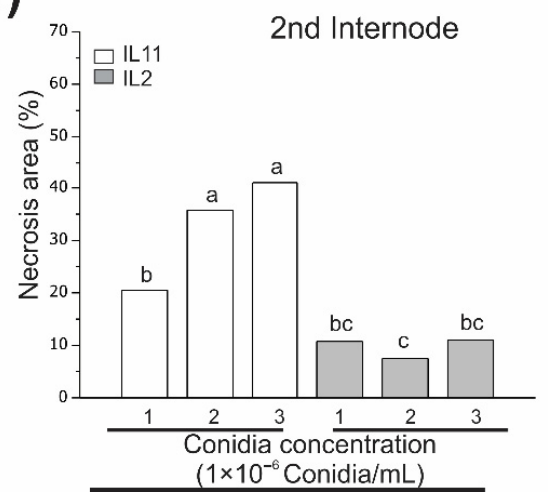

Figure 4. Fusarium effect in stalks at the silking (R1 stage). Necrosis phenotypes for the first and second internodes of the IL11 (a) and IL2 lines (b). Data were recorded 30 days post-inoculation and were analyzed using Image [48]. The stalk control value was subtracted from the infected stalk values. The graphics show the quantitative necrosis area of each genotype in the (c) first and (d) second internodes caused by the infection. The different letters above the bars refer to significant differences using the Duncan mean test $(\alpha=0.01 ; \mathrm{n}=10)$. The experiments were performed three times with a completely randomized design.

\subsection{Fv Infection with Eight Million Conidia Was Effective for Screening Resistant Genotypes (Ear Rot)}

Since Fusarium rot is among the most studied maize rots around the world [54,55], we decided to evaluate the effect of its artificial inoculation on ears as a means to differentiate between resistant and susceptible genotypes. Contrasting effects could be observed with the 8 million conidia/mL concentration (two sites of inoculation, 4 million conidia per site). The two-way analysis of variance (Table S5) of maize ear rot resistance test showed significant differences. For the IL11 genotype, 95.8\% of the grains were damaged (Figure 5a), whereas the IL1 genotype had a very low percent of affection (around $0.73 \pm 0.39 \%$; Figure $5 \mathrm{~b}$ ). These results suggest that our protocol and the doses employed can efficiently discriminate between resistant and susceptible genotypes, and that the conidia concentration presented here can be considered for screening and selecting against $\mathrm{Fv}$ ear rot. 
(a)

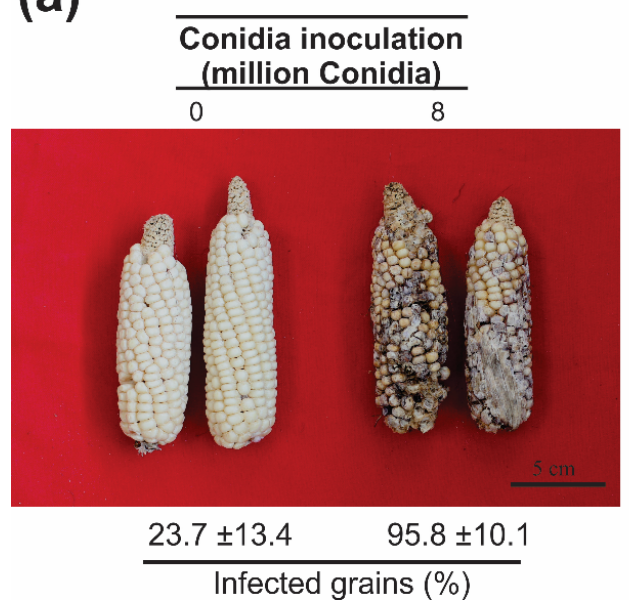

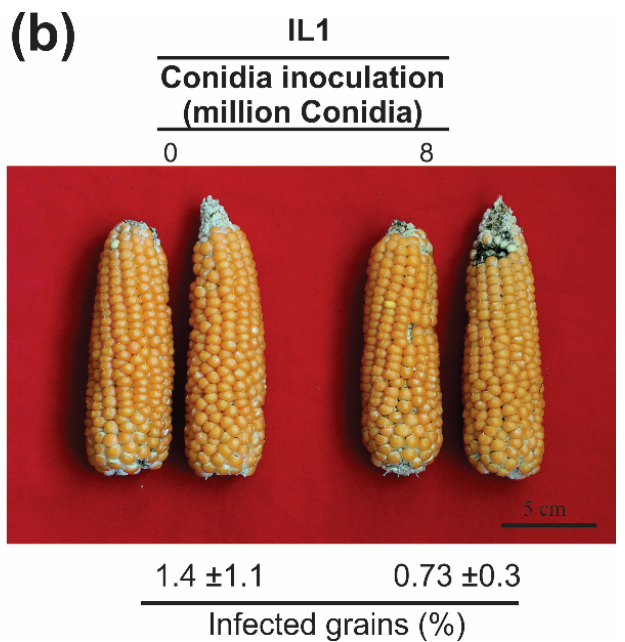

Figure 5. Fusarium effect on ears at the maturity (R6 stage). (a) Ears from the IL1 and (b) IL11 lines. In both panels, the ears on the left are the controls, whereas inoculated ears are on the right. Rot severity quantification was performed at the end of the cycle. The values show the percentage of infected grains. The different letters above the bars refer to significant differences using the Duncan mean test $(\alpha=0.01$; $\mathrm{n}=10$ ). The experiments were performed three times with a completely randomized design.

\subsection{Behavior of IL throughout the Maize Life Cycle-Fv Rots}

We selected one dose to evaluate from each physiological phase, which could screen contrasting genotypes. As in the post germinative VE assay and seedling rot assay at V2, the seeds are inoculated in same way; we chose to evaluate the V2 stage (one million conidia/mL), the V4 stage ( $12.5 \mathrm{~g}$ maize- $\mathrm{Fv}$ per L substrate), the R1 stage ( 3 million conidia/mL), and the R6 stage (4 million conidia/mL) in two injection sites. A hierarchical clustering analysis was performed using the most informative parameters such as severity, fresh root weight, and aerial length, which made it possible to observe contrasting phenotypes (Table 1). For example, IL1, IL2, IL14, and IL17 were tolerant/resistant in all stages evaluated, whereas IL11 and IL12 were susceptible throughout the life cycle. In addition, IL10 was susceptible in the V2, V4, and R1 stages, whereas it presented resistance at the R6 stage.

Table 1. Summary of the behavior of inbred lines at screening during the maize life cycle.

\begin{tabular}{ccccc}
\hline & & Stage of Development & \\
\hline Genotypes & V2 (Seedling) & V4 (Plantlet) & R1 (Stalk) & R6 (Ears) \\
\hline IL1 & Tolerant & Tolerant & Resistant & Resistant \\
\hline IL2 & Highly tolerant & Tolerant & Resistant & Resistant \\
\hline IL10 & Highly susceptible & Susceptible & Susceptible & Resistant \\
\hline IL11 & Susceptible & Highly susceptible & Susceptible & Susceptible \\
\hline IL12 & Susceptible & Susceptible & Susceptible & Susceptible \\
\hline IL14 & Highly tolerant & Tolerant & Resistant & Resistant \\
\hline IL17 & Highly tolerant & Tolerant & Resistant & Resistant \\
\hline
\end{tabular}

\section{Discussion}

Rots caused by Fusarium species have destructive consequences worldwide, although they are particularly widespread in maize-producing areas [35]. When these pathogens are predominant in an area, they can inflict considerable yield loss on maize production [8,30,31]. In addition, this crop disease can disperse toxins through infected gains, which is a potential health risk for humans and animals [13-15]. One of the most effective ways to diminish this problem is through developing 
highly tolerant or resistant maize plants. The first step towards accomplishing this would be to identify and select tolerant germplasm sources for the development of hybrid parents or populations. Since Fusarium species are hemibiotrophs [35] and they can infect maize at any stage of development, screening assays for phenotype selection in the vegetative and reproductive stages are necessary.

In our study, we evaluated five important physiological stages of the maize life cycle using different dose-responses, which allowed us to screen maize genotypes for tolerance/resistance or susceptibility to $F v$ rots. Specifically, we evaluated the effect of $F v$ on the seed rot at the post-germination (VE stage). The effect of this was slightly adverse, and in some cases it stimulated the growth of roots and coleoptiles without affecting germination (Figure 1). Similar behaviors were observed in two other infected maize seed studies employing F. moniliforme [56] and F. graminearum [57], in which germination was not affected by the infection. However, Yates et al. [56] did find a negative influence on early seedling growth in maize using F. moniliforme. Here, we observed that some genotypes had a positive growth effect in comparison to the control (see the IL17 genotype in Figure 1). This is not an isolated case since it is well known that Fv belongs to the Gibberella fujikuroi species complex, which produces gibberellins [58] that stimulate both cell elongation by cell wall loosening $[59,60]$ and premature seed germination by vivipary [61]. Therefore, it is very likely that our $F v$ isolates stimulate shoot elongation through this mechanism. However, even when we observed small variations in comparison to our control tests, we were able to identify contrasting phenotypes between genotypes.

The maize V2 stage was challenged by Fv to study seedling root rot using the rolled paper assay, in which we found that the three conidia doses exhibited significant differences between inbred lines (Figure 2). One million conidia has been reported as an effective concentration to infect maize, and Leyva-Madrigal et al. [20] used this concentration to detect high severities with F. verticillioides (FVDA42; 90\% severity) and F. nygamai (FnCI62; 88\% severity). The authors also observed a reduction in seedling height from $35 \%$ to $50 \%$ (in comparison to the control), with the only negative correlation found between seedling severity and height [20]. Here, we observed a similar response percentage in the inbred lines. Nonetheless, our analysis revealed negative correlations between severity and such seedling growth variables as height and the fresh weight of aerial and root tissues. The effect of conidia doses; thus, provided us with a means to distinguish between contrasting (i.e., susceptible and tolerant) phenotypes.

Since maize Fusarium blight can be observed during the first weeks after planting seeds [50], it is important to establish a protocol that can evaluate this stage of the plant for the selection of tolerant genotypes. We tested the $\mathrm{V} 4$ maize stage using four different $F v$ conidia concentrations (Figure 3) and observed that the infection was more severe in the IL12 genotype, affecting its growth in each treatment. Meanwhile, the IL14 showed this negative effect when the highest doses were used. Unsurprisingly, the roots were the most affected tissue. Indeed, plants with infected roots grew weakly, due to their inability to capture nutrients from the soil and transport them to their aerial parts. This can have a considerable effect on grain filling, which can consequently reduce yield from $10 \%$ to $25 \%$ [8]. Yates et al. [56] observed that the growth of seedlings infected with F. moniliforme was suppressed temporarily during the first days after sowing, although the growth of these infected plants was accelerated to the same level or higher of non-infected plants after four weeks. This growth stimulation could be due to gibberellin production by Fusarium [62]. Moreover, Leyva-Madrigal et al. [20] observed an increase in plant height and reduced stalk thickness when plants were infected with $F$. thapsinum, whereas plant height was reduced when using F. verticillioides, F. nygamai, and F. andiyazi. In our evaluation of the seven inbred lines, we did not observe any plant height stimulation or reduced stalk thickness in response to $F v$. Importantly, the four doses that we evaluated here were capable of differentiating tolerant from susceptible genotypes.

Fusarium stalk rot has been detected on every continent, and it can reduce grain weight by up to $20 \%$ and yield by up to $38 \%[63,64]$. This infection interferes with the movement of water and nutrients, and is one of the main causes of stalk lodging, which can lead to premature plant death [65]. The use of resistant genotypes is an effective, safe, and environmentally friendly approach against Fusarium 
stalk rot [66]. Although numerous reports have been published regarding an increase in resistance to Fusarium sp. stalk rot in maize [67-72], no fully immune genotype has yet been reported. In the present study, we used the needle inoculation method [41] to evaluate the dose-response concentration in the first and second stalk internodes, employing native $F v$ strains that were isolated from cultivated maize fields in the subtropical area of northwest Mexico [20]. We; thus, determined that injecting a concentration of three million conidia could be used to effectively differentiate contrasting genotypes (Figure 4). In the susceptible genotype, the necrosis area was dependent on conidia concentration and had a positive correlation, whereas no correlation was found between conidia concentration and the necrosis area in the tolerant genotype. A range of phenotypes were observed, ranging from highly susceptible to moderately tolerant to highly tolerant (unpublished data). Similar results have been found in other studies using different inoculum concentrations in other regions of the world [69,72]. Contrary to what we report here, Mendoza Elos, et al. [73] observed susceptible and resistant inbred plants that displayed a full range of damage (from $0 \%$ to $100 \%$ ), although in a second assay 22 out of 23 inbreeds lines displayed damage ranging from $75 \%$ to $100 \%$. The differences between the two experiments could be due to the lack of quantitative techniques and/or the environmental conditions affecting the inoculum. Since we only tested the stalk inoculation at the plant flowering time, it could be interesting to investigate the stalk field inoculation at earlier plant stages to evaluate if the fungus is capable of moving throughout the stem to reach other organs, such as the ear. Interestingly, this approach has only been conducted in greenhouse pot assays to date [33]. We show here that in comparison to other techniques [69], needle inoculation is one of the fastest and easiest approaches for evaluating large populations of maize that are common in breeding programs.

Since the ear is the main product harvested from maize, it is important to consider the selection of quality ears and kernels that are also mycotoxin-free. The best alternative to reduce the concentration of mycotoxins in grains is to develop resistant or highly tolerant genotypes by genetic improvement [54]. In our work, we evaluated the inoculation of ears by the needle method [41] with a total concentration of eight million conidia per ear, which allowed us to record contrasting genotypes (Figure 5). A wide range of conidia concentrations has already been evaluated in ear rot, from 0.5 to 20 million [74-76]. However, these studies did not demonstrate any contrasting phenotypes in comparison to our study. This could be associated with the highly aggressive Fv strain used in our study, which can be used to select resistant genotypes with low fumonisin concentrations due to the positive correlation between damaged kernels and fumonisin levels [77]. The ability to distinguish resistant from susceptible genotypes in a maize collection, and to identify the factors associated with the infection of kernels by $F v$, will greatly help in dissecting the molecular and physiological mechanisms associated with plant-pathogen interactions. In addition, this will improve our knowledge of the selection of genotypes that could be resistant to $F v$ infection. Factors including pericarp thickness [78] and a high content of phenolic compounds [79], such as ferulic acid [80,81], flavonoids [82], and anthocyanins [83], in the pericarp and aleurone tissue could be useful in plant breeding programs in order to find maize genotypes that are resistant $F v$ infection.

\section{Conclusions}

This study was conducted in order to develop a strategy that can be used to select between F. verticillioides tolerant/resistant and susceptible maize genotypes throughout the maize life cycle. Five assays were effective at distinguishing contrasting phenotypes. These assays and the concentrations that we used will be helpful as an initial disease indicator, or as a first means to track the genomic regions responsible for tolerance/resistant or susceptibility. The inoculation of stalks and ears by needles proved to be a high-throughput method capable of screening large populations during the maize reproductive stage in our maize breeding program, which will facilitate developing maize genotypes with improved $F v$ resistance. The range of doses and the types of assays in our study could serve as a reference for other highly virulent Fusarium species, such as F. nygamai (FnCI62), which will help to obtain similar results [84]. We observed a phenotypic pattern of response to infection by 
Fv throughout the maize life cycle (Table 1 ), in which IL that were susceptible during the first stage were also susceptible at the reproductive stage. A similar pattern was observed for the IL classified as tolerant or resistent. This capacity was conserved in $85 \%$ of IL ( 6 out of 7 ). The present study is the first report in which several stages of maize development were challenged with $F v$ to classify tolerant/resistant and susceptible genotypes. Screening at an initial stage of development, such as V2, could be useful for predicting the response of genotypes at the reproductive stage, such as ear rot or stalk rot. We; therefore, recommend the combination of these assays for selecting resistant or tolerant maize genotypes against Fusarium rots in breeding programs.

Supplementary Materials: The following are available online at http://www.mdpi.com/2073-4395/10/12/1990/s1, Table S1: Two-way analysis of variance (ANOVA) of post-germinative seedling rot dose-response assay at the VE stage, Table S2: Two-way analysis of variance (ANOVA) of seedling rot dose-response assay at the V2 stage, Table S3: Two-way analysis of variance (ANOVA) of plantlet rot assay at the V4 stage, Table S4: Two-way analysis of variance (ANOVA) of stalk rot resistance assay, Table S5: Two-way analysis of variance (ANOVA) of maize ear rot resistance tests.

Author Contributions: Conceptualization, F.R.Q.-F.; data curation, S.G.R. and E.N.-P.; formal analysis, S.G.R. and F.R.Q.-F.; funding acquisition, F.R.Q.-F.; investigation, S.G.R., J.Q.-C., M.V. and V.U.-G.; methodology, S.G.R., J.Q.-C., M.V. and V.U.-G.; project administration, F.R.Q.-F.; writing-original draft, E.R.-M., R.K.S., L.S. and F.R.Q.-F.; writing-review and editing, J.Q.-C., E.R.-M., R.K.S., L.S. and F.R.Q.-F. All authors have read and agreed to the published version of the manuscript.

Funding: This research was funded by the National Council on Science and Technology (CONACyT) under Grants 250738-Infraestructura and 1070-Fronteras de la ciencia; Secretaria de Investigación y Posgrado del Instituto Politécnico Nacional (SIP-IPN) under Grants no. 20150712, 20161683, and 20195805.

Acknowledgments: We are grateful to Brandon Loveall for proofreading the manuscript.

Conflicts of Interest: The authors declare no conflict of interest.

\section{References}

1. Ranum, P.; Pena-Rosas, J.P.; Garcia-Casal, M.N. Global maize production, utilization, and consumption. Ann. N. Y. Acad. Sci. 2014, 1312, 105-112. [CrossRef] [PubMed]

2. Koohafkan, P.; Stewart, B.A. Cereal Production in Drylands; Koohafkan, P., Stewart, B.A., Eds.; Food and Agriculture Organization of the United Nations: Rome, Italy, 2008; pp. 17-23.

3. Power, A.G. Plant community diversity, herbivore movement, and an insect-transmitted disease of maize. Ecology 1987, 68, 1658-1669. [CrossRef] [PubMed]

4. Liu, K.J.; Goodman, M.; Muse, S.; Smith, J.S.; Buckler, E.; Doebley, J. Genetic structure and diversity among maize inbred lines as inferred from DNA microsatellites. Genetics 2003, 165, 2117-2128. [PubMed]

5. Holbert, J.R.; Burlison, W.L.; Koehler, B.; Woodworth, C.M.; Dungan, G.H. Corn Root, Stalk, and Ear Rot Diseases, and Their Control thru Seed Selection and Breeding; University of Illinios, Agricultural Experiment Station: Urbana, IL, USA, 1924; pp. 1-478.

6. Munkvold, G.P. Epidemiology of Fusarium diseases and their mycotoxins in maize ears. Eur. J. Plant Pathol. 2003, 109, 705-713. [CrossRef]

7. Nagy, E.; Voichita, H.; Kadar, R. The influence of Fusarium ear infection on the maize yield and quality (Transylvania-Romania). Commun. Agric. Appl. Biol. Sci. 2006, 71, 1147-1150.

8. Lizárraga-Sánchez, G.J.; Leyva-Madrigal, K.Y.; Sánchez-Peña, P.; Quiroz-Figueroa, F.R.; Maldonado-Mendoza, I.E. Bacillus cereus sensu lato strain B25 controls maize stalk and ear rot in Sinaloa, Mexico. Field Crop Res. 2015, 176, 11-21. [CrossRef]

9. Nagy, E.; Haş, V.; Haş, I.; Suciu, A.; Florian, V. Fusarium ear infection on the maize yield and mycotoxin content (Transylvania-Romania). Breed. Seed Sci. 2012, 64, 10. [CrossRef]

10. Rosiles, M.R.; Bautista, J.; Fuentes, V.O.; Ross, F. An outbreak of equine leukoencephalomalacia at Oaxaca, Mexico, associated with fumonisin B1. J. Vet. Med. Ser. A Physiol. Pathol. Clin. Med. 1998, 45, $299-302$. [CrossRef] 
11. Ross, P.F.; Nelson, P.E.; Richard, J.L.; Osweiler, G.D.; Rice, L.G.; Plattner, R.D.; Wilson, T.M. Production of fumonisins by Fusarium moniliforme and Fusarium proliferatum isolates associated with equine leukoencephalomalacia and a pulmonary edema syndrome in swine. Appl. Environ. Microbiol. 1990, 56, 3225-3226. [CrossRef]

12. Riley, R.T.; Voss, K.A.; Speer, M.; Stevens, V.L.; Waes, J.G.-V. Fumonisin inhibition of ceramide synthease: A possible risk factor for human nueral tube defects. In Sphingolipid Biology, 1st ed.; Hirabayashi, Y., Igarashi, Y., Merrill, A.H., Eds.; Springer: Tokyo, Japan; Berlin/Heidelberg, Germany; New York, NY, USA, 2006; pp. 345-361.

13. Vanzinni Zago, V.; Manzano-Gayosso, P.; Hernández-Hernández, F. Queratomicosis en un centro de atención oftalmológica en la Ciudad de México. Rev. Iberoam. Micol. 2010, 27, 57-61. [CrossRef]

14. Galletti, J.; Negri, M.; Grassi, F.L.; Kioshima-Cotica, E.S.; Svidzinski, T.I. Fusarium spp. is able to grow and invade healthy human nails as a single source of nutrients. Eur. J. Clin. Microbiol. Infect. Dis. 2015, 34, 1767-1772. [CrossRef] [PubMed]

15. Mena, R.; Carrasco, E.; Godoy-Martínez, P.; Stchigel, A.M.; Cano-Lira, J.F.; Zaror, L. Un caso de queratitis micótica por Fusarium solani en Valdivia, Chile. Rev. Iberoam. Micol. 2015, 32, 106-110. [CrossRef] [PubMed]

16. Munkvold, G.P.; Desjardins, A.E. Fumonisins in maize-Can we reduce their occurrence? Plant Dis. 1997, 81, 556-565. [CrossRef] [PubMed]

17. Román, S.G. Caracterización de Genotipos de Maíz (Zea mays L.) a la Infección de Fusarium Verticillioides en Diferentes Fases del Ciclo de Vida de la Planta y su Correlación con Marcadores Moleculares de Tipo SNPs; Instituto Politécnico Nacional: Guasave, Sinaloa, Mexico, 2017.

18. Görtz, A.; Oerke, E.C.; Steiner, U.; Waalwijk, C.; de Vries, I.; Dehne, H.W. Biodiversity of Fusarium species causing ear rot of maize in Germany. Cereal Res. Commu. 2008, 36, 617-622. [CrossRef]

19. Duan, C.; Qin, Z.; Yang, Z.; Li, W.; Sun, S.; Zhu, Z.; Wang, X. Identification of pathogenic Fusarium spp. causing maize ear rot and potential mycotoxin production in China. Toxins 2016, 8, 186. [CrossRef]

20. Leyva-Madrigal, K.Y.; Larralde-Corona, C.P.; Apodaca-Sánchez, M.A.; Quiroz-Figueroa, F.R.; Mexia-Bolaños, P.A.; Portillo-Valenzuela, S.; Ordaz-Ochoa, J.; Maldonado-Mendoza, I.E. Fusarium species from the Fusarium fujikuroi species complex involved in mixed infections of maize in northern Sinaloa, Mexico. J. Phytopathol. 2015, 163, 486-497. [CrossRef]

21. Aguin, O.; Cao, A.; Pintos, C.; Santiago, R.; Mansilla, P.; Butron, A. Occurrence of Fusarium species in maize kernels grown in northwestern Spain. Plant Pathol. 2014, 63, 946-951. [CrossRef]

22. Stumpf, R.; dos Santos, J.; Gomes, L.B.; Silva, C.N.; Tessmann, D.J.; Ferreira, F.D.; Machinski, M.; Del Ponte, E.M. Fusarium species and fumonisins associated with maize kernels produced in Rio Grande do Sul State for the 2008/09 and 2009/10 growing seasons. Braz. J. Microbiol. 2013, 44, 89-95. [CrossRef]

23. Ilze, B.; Lindy, J.R.; Gordon, S.S.; Bradley, C.F.; Altus, V. Mycotoxigenic Fusarium species associated with grain crops in South Africa-A review. S. Afr. J. Sci. 2017, 113, 12. [CrossRef]

24. Mueller, D.S.; Wise, K.A.; Sisson, A.J.; Allen, T.W.; Bergstrom, G.C.; Bosley, D.B.; Bradley, C.A.; Broders, K.D.; Byamukama, E.; Chilvers, M.I.; et al. Corn yield loss estimates due to diseases in the United States and Ontario, Canada from 2012 to 2015. Plant Health Prog. 2016, 17, 12. [CrossRef]

25. Ortiz, C.S.; Richards, C.; Terry, A.; Parra, J.; Shim, W.B. Genetic variability and geographical distribution of mycotoxigenic Fusarium verticillioides strains isolated from maize fields in Texas. Plant Pathol. J. 2015, 31, 203-211. [CrossRef] [PubMed]

26. SIAP, S. Servicio de Información Agroalimentaria y Pesquera. Available online: https://nube.siap.gob.mx/ cierreagricola/ (accessed on 11 October 2020).

27. Briones-Reyes, D.; Castillo-Gonz lez, F.; Ch vez-Servia, J.L.; Aguilar-Rincón, V.; García-de Alba, C.d.L.; Ramírez-Hernández, A. Respuesta de maíz nativo del Altiplano Mexicano a pudrición de Mazorca, bajo infección natural. Agron. Mesoam. 2015, 26, 73-85. [CrossRef]

28. González Huerta, A.; Vázquez García, L.M.; Sahagún Castellanos, J.; Rodríguez Pérez, J.E.; Pérez López, D.d.J. Rendimiento del maíz de temporal y su relación con la pudrición de mazorca. Agric. Téc. Méx. 2007, $33,33-42$.

29. Quintero-Benítez, J.A.; Apodaca-Sánchez, M.A. Las pudriciones de tallos de maíz y su manejo en Sinaloa. In Manejo Sustentable del Maíz; Universidad Autónoma de Sinaloa; Fundación Produce Sinaloa; SAGARPA; Gobierno del Estado de Sinaloa: Culiacán, Mexico, 2008; pp. 67-70. (In Spanish) 
30. Apodaca-Sánchez, M.A.; Quintero-Benítez, J.A. Pudrición de mazorca. In Manejo Sustentable del Maíz; Universidad Auntónoma de Sinaloa; Fundación Produce Sinaloa; SAGARPA; Gobierno del Estado de Sinaloa: Culiacán, Mexico, 2008; pp. 71-78.

31. García Pérez, R.D.; Velarde Félix, S.; Garzón Tiznado, J.A.; Ureta Tellez, J. Distribución geográfica y caracterización molecular de Fusarium spp. en el centro-sur de Sinaloa y respuesta de variedades de maíz al ataque de este patógeno. In Avances de Investigación 2011 del CEVACU; Instituto Nacional de Investigaciones Forestales, Agrícolas y Pecuarias: Mexico City, Mexico, 2012; Volume 15, pp. 15-19.

32. Duncan, K.E.; Howard, R.J. Biology of maize kernel infection by Fusarium verticillioides. Mol. Plant Microbe Interact. 2010, 23, 6-16. [CrossRef] [PubMed]

33. Gai, X.; Dong, H.; Wang, S.; Liu, B.; Zhang, Z.; Li, X.; Gao, Z. Infection cycle of maize stalk rot and ear rot caused by Fusarium verticillioides. PLoS ONE 2018, 13, e0201588. [CrossRef] [PubMed]

34. Munkvold, G.P.; McGee, D.C.; Carlton, W.M. Importance of different pathways for maize kernel infection by Fusarium moniliforme. Phytopathology 1997, 87, 209-217. [CrossRef] [PubMed]

35. Ma, L.J.; Geiser, D.M.; Proctor, R.H.; Rooney, A.P.; O’Donnell, K.; Trail, F.; Gardiner, D.M.; Manners, J.M.; Kazan, K. Fusarium pathogenomics. Annu. Rev. Microbiol. 2013, 67, 399-416. [CrossRef] [PubMed]

36. Dorn, B.; Forrer, H.R.; Jenny, E.; Wettstein, F.E.; Bucheli, T.D.; Vogelgsang, S. Fusarium species complex and mycotoxins in grain maize from maize hybrid trials and from grower's fields. J. Appl. Microbiol. 2011, 111, 693-706. [CrossRef]

37. Zila, C.T.; Ogut, F.; Romay, M.C.; Gardner, C.A.; Buckler, E.S.; Holland, J.B. Genome-wide association study of Fusarium ear rot disease in the U.S.A. maize inbred line collection. BMC Plant Biol. 2014, 14, 372. [CrossRef]

38. Stagnati, L.; Lanubile, A.; Samayoa, L.F.; Bragalanti, M.; Giorni, P.; Busconi, M.; Holland, J.B.; Marocco, A. A genome wide association study reveals markers and genes associated with resistance to Fusarium verticillioides infection of seedlings in a maize diversity panel. G3 Genes Genom. Genet. 2019, 9, 571-579. [CrossRef]

39. Mesterházy, Á.; Lemmens, M.; Reid, L.M. Breeding for resistance to ear rots caused by Fusarium spp. in maize-A review. Plant Breed. 2012, 131, 1-19.

40. Warham, E.J.; Butler, L.D.; Sutton, B.C. Seed Testing of Maize and Wheat: A Laboratory Guide; CIMMYT: Mexico City, Mexico, 1996; pp. 1-84.

41. Reid, L.M.; Zhu, X. Screening Corn for Resistance to Common Diseases in Canada; Agriculture and Agri-Food Canada: Ottawa, ON, Canada, 2005; pp. 1-29.

42. Al-Juboory, H.; Juber, K.S. Efficiency of some inoculation methods of Fusarium proliferatum and F.verticillioides on the systemic infection and seed transmission on maize under field conditions. Agric. Biol. J. N. Am. 2013, 4, 583-589. [CrossRef]

43. Clements, M.J.; Kleinschmidt, C.E.; Maragos, C.M.; Pataky, J.K.; White, D.G. Evaluation of inoculation techniques for Fusarium ear rot and fumonisin contamination of corn. Plant Dis. 2003, 87, 147-153. [CrossRef]

44. Mario, J.L.; Reis, E.M.; Juliatti, F.C. Three inoculation methods for screening corn germplasm to white ear rot resistance. Trop. Plant Pathol. 2011, 36, 362-366.

45. Leslie, J.F.; Summerell, B.A. The Fusarium Laboratory Manual; Blackwell Publishing Ltd.: Hoboken, NJ, USA; Oxford, UK; Milton, Australia, 2007; Volume 2, pp. 1-369.

46. García Espinoza, J.A. Asociación de Fusarium Verticillioides (Sacc.) Nir. a Semilla de Zea Mays L. en Sinaloa y su Control In Vitro Mediante Procloraz. Escuela Superior de Agricultura del Valle del Fuerte; Universidad Autónoma de Sinaloa: Juan José Ríos, Sinaloa, Mexico, 2009.

47. Soonthornpoct, P.; Trevathan, L.E.; Gonzalez, M.S.; Tomaso-Peterson, M. Fungal occurrence, disease incidence and severity, and yield of maize symptomatic for seedling disease in Mississippi. Mycopathologia 2001, 150, 39-46. [CrossRef] [PubMed]

48. Abramoff, M.D.; Magalhaes, P.J.; Ram, S.J. Image processing with ImageJ. Biophotonics Intern. 2004, 11, 36-41.

49. Munkvold, G.P.; Hellmich, R.L.; Showers, W.B. Reduced Fusarium ear rot and symptomless infection in kernels of maize genetically engineered for European corn borer resistance. Phytopathology 1997, 87, 1071-1077. [CrossRef] [PubMed]

50. Thomas, M.D.; Buddenhagen, I.W. Incidence and persistence of Fusarium moniliforme in symptomless maize kernels and seedlings in Nigeria. Mycologia 1980, 72, 882-887. [CrossRef] 
51. Quesada-Ocampo, L.M.; Al-Haddad, J.; Scruggs, A.C.; Buell, C.R.; Trail, F. Susceptibility of maize to stalk rot caused by Fusarium graminearum deoxynivalenol and zearalenone mutants. Phytopathology 2016, 106, 920-927. [CrossRef]

52. Borah, S.N.; Deka, S.; Sarma, H.K. First Report of Fusarium verticillioides causing stalk rot of maize in Assam, India. Plant Dis. 2016, 100, 1501. [CrossRef]

53. Shin, J.H.; Han, J.H.; Lee, J.K.; Kim, K.S. Characterization of the maize stalk rot pathogens Fusarium subglutinans and F. temperatum and the effect of fungicides on their mycelial growth and colony formation. Plant Pathol. J. 2014, 30, 397-406. [CrossRef] [PubMed]

54. Lanubile, A.; Maschietto, V.; Borrelli, V.M.; Stagnati, L.; Logrieco, A.F.; Marocco, A. Molecular basis of resistance to Fusarium ear rot in maize. Front. Plant Sci. 2017, 8, 1774. [CrossRef] [PubMed]

55. Santiago, R.; Cao, A.; Butron, A. Genetic factors involved in fumonisin accumulation in maize kernels and their implications in maize agronomic management and breeding. Toxins 2015, 7, 3267-3296. [CrossRef]

56. Yates, I.E.; Bacon, C.W.; Hinton, D.M. Effects of endophytic infection by Fusarium moniliforme on corn growth and cellular morphology. Plant Dis. 1997, 81, 723-728. [CrossRef] [PubMed]

57. Galli, J.A.; Fessel, S.A.; Panizzi, R.C. Effect of Fusarium graminearum and infection index on germination and vigor of maize seeds. Fitopatol. Bras. 2005, 30, 5. [CrossRef]

58. Troncoso, C.; Gonzalez, X.; Bomke, C.; Tudzynski, B.; Gong, F.; Hedden, P.; Rojas, M.C. Gibberellin biosynthesis and gibberellin oxidase activities in Fusarium sacchari, Fusarium konzum and Fusarium subglutinans strains. Phytochemistry 2010, 71, 1322-1331. [CrossRef] [PubMed]

59. Jones, R.L.; Kaufman, P.B. The role of gibberellins in plant cell elongation. Crit. Rev. Plant Sci. 1983, 1, $23-47$. [CrossRef]

60. Cosgrove, D.J. Catalysts of plant cell wall loosening. F1000Research 2016, 5. [CrossRef]

61. Quiroz-Figueroa, F.R.; Quiroz-Chávez, J.; García-Pérez, L.M.; Roman, S.G. Mejoramiento genético del maíz el caso de la fusariosis. Cienc. Y Desarro. 2016, 281, 41-49.

62. Hedden, P.; Sponsel, V. A century of gibberellin research. J. Plant Growth Regul. 2015, 34, 740-760. [CrossRef]

63. Kenganal, M.; Patil, M.B.; Nimbaragi, Y. Management of stalk rot of maize caused by Fusarium moniliforme (Sheldon). Int. J. Curr. Microbiol. App. Sci. 2017, 6, 7.

64. Khokhar, M.K.; Hooda, K.S.; Sharma, S.S.; Singh, V. Post flowering stalk rot complex of maize-Present status and future prospects. Maydica 2014, 59, 16.

65. Christensen, J.J.; Wilcoxson, R.D. Stalk Rot of Corn; The American Phytopathlogical Society: Saint Paul, MN, USA, 1966; Volume 3, pp. 1-59.

66. Gopala; Gogoi, R.; Hooda, K.S.; Rai, S.N.; Kumar, A.; Hossain, F. Rapid screening technique for evaluation of maize genotypes against stalk rot complex caused by Macrophomina phaseolina and Fusarium verticilloides. Indian J. Agr. Sci. 2016, 86, 1024-1030.

67. Yang, D.E.; Zhang, C.L.; Zhang, D.S.; Jin, D.M.; Weng, M.L.; Chen, S.J.; Nguyen, H.; Wang, B. Genetic analysis and molecular mapping of maize (Zea mays L.) stalk rot resistant gene Rfg1. Appl. Genet. 2004, 108, 706-711. [CrossRef]

68. Yang, D.E.; Jin, D.M.; Wang, B.; Zhang, D.S.; Nguyen, H.T.; Zhang, C.L.; Chen, S.J. Characterization and mapping of Rpi1, a gene that confers dominant resistance to stalk rot in maize. Mol. Genet. Genom. 2005, 274, 229-234. [CrossRef]

69. Yang, Q.; Yin, G.; Guo, Y.; Zhang, D.; Chen, S.; Xu, M. A major QTL for resistance to Gibberella stalk rot in maize. Appl. Genet. 2010, 121, 673-687. [CrossRef]

70. Chen, Q.; Song, J.; Du, W.P.; Xu, L.Y.; Jiang, Y.; Zhang, J.; Xiang, X.L.; Yu, G.R. Identification, mapping, and molecular marker development for Rgsr8.1: A new quantitative trait locus conferring resistance to gibberella stalk rot in maize (Zea mays L.). Front Plant Sci. 2017, 8, 1355. [CrossRef]

71. Ma, C.Y.; Ma, X.N.; Yao, L.S.; Liu, Y.J.; Du, F.L.; Yang, X.H.; Xu, M.L. Qrfg3, a novel quantitative resistance locus against Gibberella stalk rot in maize. Appl. Genet. 2017, 130, 1723-1734. [CrossRef]

72. Wang, C.; Yang, Q.; Wang, W.; Li, Y.; Guo, Y.; Zhang, D.; Ma, X.; Song, W.; Zhao, J.; Xu, M. A transposon-directed epigenetic change in ZmCCT underlies quantitative resistance to Gibberella stalk rot in maize. New Phytol. 2017, 215, 1503-1515. [CrossRef]

73. Mendoza Elos, M.; Andrio Enríquez, E.; López Benítez, A.; Rodríguez Guerra, R.; Latournerie Moreno, L.; Rodríguez Herrera, S.A. Tasa de infección de la pudrición del tallo en maíz causada por Fusarium moniliforme. Agron. Mesoam. 2006, 17, 6. [CrossRef] 
74. Presello, D.A.; Iglesias, J.; Botta, G.; Reid, L.M.; Lori, G.A.; Eyhérabide, G.H. Stability of maize resistance to the ear rots caused by Fusarium graminearum and F. verticillioides in Argentinian and Canadian environments. Euphytica 2006, 147, 403-407. [CrossRef]

75. Ding, J.Q.; Wang, X.M.; Chander, S.; Yan, J.B.; Li, J.S. QTL mapping of resistance to Fusarium ear rot using a RIL population in maize. Mol. Breed. 2008, 22, 395-403. [CrossRef]

76. Robertson-Hoyt, L.A.; Jines, M.P.; Balint-Kurti, P.J.; Kleinschmidt, C.E.; White, D.G.; Payne, G.A.; Maragos, C.M.; Molnr, T.L.; Holland, J.B. QTL mapping for Fusarium ear rot and fumonisin contamination resistance in two maize populations. Crop Sci. 2006, 46, 1734-1743. [CrossRef]

77. Ono, E.Y.S.; Biazon, L.; da Silva, M.; Vizoni, E.; Sugiura, Y.; Ueno, Y.; Hirooka, E.Y. Fumonisins in corn: Correlation with Fusarium sp. count, damaged kernels, protein and lipid content. Braz. Arch. Biol. Techn. 2006, 49, 63-71. [CrossRef]

78. Hoenisch, R.W.; Davis, R.M. Relationship between Kernel Pericarp Thickness and Susceptibility to Fusarium Ear Rot in-Field Corn. Plant Dis. 1994, 78, 517-519. [CrossRef]

79. Sen, A.; Bergvinson, D.; Miller, S.S.; Atkinson, J.; Fulcher, R.G.; Arnason, J.T. Distribution and microchemical detection of phenolic-acids, flavonoids, and phenolic-acid amides in maize kernels. J. Agric. Food Chem. 1994, 42, 1879-1883. [CrossRef]

80. Bily, A.C.; Reid, L.M.; Taylor, J.H.; Johnston, D.; Malouin, C.; Burt, A.J.; Bakan, B.; Regnault-Roger, C.; Pauls, K.P.; Arnason, J.T.; et al. Dehydrodimers of ferulic acid in maize grain pericarp and aleurone: Resistance factors to Fusarium graminearum. Phytopathology 2003, 93, 712-719. [CrossRef]

81. Sampietro, D.A.; Fauguel, C.M.; Vattuone, M.A.; Presello, D.A.; Catalan, C.A.N. Phenylpropanoids from maize pericarp: Resistance factors to kernel infection and fumonisin accumulation by Fusarium verticillioides. Eur. J. Plant Pathol. 2013, 135, 105-113. [CrossRef]

82. Atanasova-Penichon, V.; Barreau, C.; Richard-Forget, F. Antioxidant secondary metabolites in cereals: Potential involvement in resistance to Fusarium and mycotoxin accumulation. Front. Microbiol. 2016, 7, 566. [CrossRef]

83. Bernardi, J.; Stagnati, L.; Lucini, L.; Rocchetti, G.; Lanubile, A.; Cortellini, C.; De Poli, G.; Busconi, M.; Marocco, A. Phenolic profile and susceptibility to Fusarium infection of pigmented maize cultivars. Front. Plant. Sci. 2018, 9, 1189. [CrossRef]

84. Rosas Jáuregui, M.G. Evaluación de Parentrales de Maíz (Zea mays L.) a la Infección por el Fitopatógeno Fusarium Nygamai Bajo Condiciones de Invernadero; Instituto Tecnológico del Vaye del Yaqui: San Ignacio Río Muerto, Sonora, Mexico, 2016.

Publisher's Note: MDPI stays neutral with regard to jurisdictional claims in published maps and institutional affiliations.

(C) 2020 by the authors. Licensee MDPI, Basel, Switzerland. This article is an open access article distributed under the terms and conditions of the Creative Commons Attribution (CC BY) license (http://creativecommons.org/licenses/by/4.0/). 